International Journal of Scholarly Papers for Media and Communications

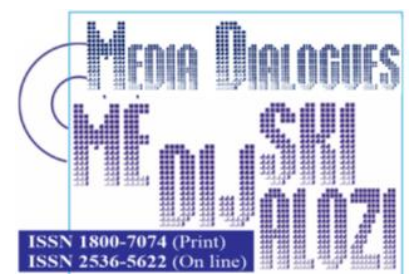

Baltezarevic, R., Baltezarevic, I. (2020), „The Role of Social Media in Corporate Social Responsibility - Fashion Industry Confronting the Challenges of the Modern Age", Media Dialogues / Medijski dijalozi, Vol. 13, No. 3, pp. 7-22.

\title{
The Role of Social Media in Corporate Social Responsibility - Fashion Industry Confronting the Challenges of the Modern Age
}

\section{Uloga društvenih medija u korporativnoj društvenoj odgovornosti - suprotstavljanje modne industrije izazovima modernog vremena}

\author{
Professor RADOSLAV BALTEZAREVIC, \\ Higher School of Communication, \\ Belgrade, Serbia
}

IVANA BALTEZAREVIC, PhD candidate Faculty of Culture and Media,

Belgrade, Serbia

\begin{tabular}{|c|c|}
\hline $\boldsymbol{A} \boldsymbol{R} \boldsymbol{T} \boldsymbol{I} \boldsymbol{C L} \boldsymbol{E}$ & Received: October 10,2019 / Revised from: November 10, 2019 \\
$\boldsymbol{I} \boldsymbol{N} \boldsymbol{F} \boldsymbol{O}$ & Accepted: December 10, 2019 / Available online: April 15, 2020 \\
\hline DOI & doi.org/10.14254/1800-7074/13-2/1 \\
\hline
\end{tabular}




\section{ABSTRACT}

In modern society we are witnessing the growing competition among companies due to the deregulation of the international economic ambiance, global market, development of information technologies and information availability, cheap and welltrained labor force and increased productivity. Guided primarily by the desire to maintain and improve their competitive edge and develop their reputation capital, the companies affirmatively respond to the ethical and social requirements imposed by the community in which they operate. Social media may provide a new way to communicate CCR Responsibility efforts of Fashion industry, therefore companies are provided with opportunity to directly interact with their consumers about their strategies and CSR efforts. This paper will examine the phenomenon that the more employees and customers understand corporate philanthropy in the fashion industry, as a form of socially responsible behavior, the more it is likely that such a company will be better positioned on the market, increase its market share, promote its image, improve employee satisfaction and develop a sense of collectiveness in both the company and the society. In order to support that goal, companies should consider the possibilities provided by Social media, as well. Nowadays, in demanding market conditions, the greater the awareness and knowledge of potential customers or service users about the company's philanthropic activities in fashion industry, the higher is the probability that they opt for becoming clients of a company in which they have confidence.

KEYWORDS: Social Media, Corporate Social Responsibility, Corporate Philanthropy, Socially Responsible Operation, Developing Reputation Capital, Competitive Edge, Fashion Industry

\section{APSTRAKT}

U savremenom društvu svedoci smo sve veće konkurencije kompanija usled deregulacije međunarodnog ekonomskog ambijenta, globalnog tržišta, razvoja informacionih tehnologija i dostupnosti informacija, jeftine i dobro obučene radne snage i povećane produktivnosti. Vođene prvenstveno željom da održavaju i poboljšaju svoju konkurentsku prednost i razviju svoj kapital reputacije, kompanije afirmativno odgovaraju etičkim i socijalnim zahtevima koje postavlja zajednica u kojoj posluju. Društveni mediji mogu pružiti novi način komuniciranja korporativne društvene odgovornosti u modnoj industriji, kompanijama je pružena mogućnost da direktno komuniciraju sa svojim potrošačima u vezi sa njihovim strategijama i CSR aktivnostima. Ovaj rad će ispitati fenomen da što više zaposlenih i potrošača razume korporativnu filantropiju u modnoj industriji, kao oblik društveno odgovornog ponašanja, to je verovatnije da će se takva kompanija bolje pozicionirati na tržištu, povećati svoj tržišni udeo, promovisati svoj imidž, poboljšati zadovoljstvo zaposlenih i razviti osećaj kolektivnosti kako u kompaniji, tako i u društvu. Da bi podržale ovaj cilj, 
kompanije bi trebalo da razmotre i mogućnosti koje pružaju društveni mediji. Danas, u zahtevnijim tržišnim uslovima, što je veća svest $i$ znanje potencijalnih potrošača ili korisnika usluga o filantropskim aktivnostima kompanije u modnoj industriji, veća je verovatnoća da će se odlučiti da postanu klijenti kompanije u koju imaju poverenja.

\section{KLJUČNE REČI}

Društveni mediji, korporativna društvena odgovornost, korporativna filantropija, društveno odgovorno poslovanje, razvoj kapitala reputacije, konkurentska prednost, modna industrija

\section{INTRODUCTION}

The customers or service users influence the operation of every company with their direct or indirect ethical requirements. When deciding whether to purchase certain goods or services, the customers are normally interested not only in the product itself, its price and features but also in the method in which the targeted product was manufactured and ethical issues related to the manufacturing process and the company's attitude towards the broader social community. If certain companies use the methods that are not ethical from the point of view of the customers, latter they are prepared to punish them by not making the purchase. In accordance therewith, the companies, which are heedful of their environment, the needs of the local community in which they provide their services and their employees, have a strategic advantage over their competitors. The goal of present-day companies is to create a strong organizational structure, which they can achieve only by developing ethical guidelines and fostering the values that develop partner relations with the social community.

In recent years, the business community and the general public are increasingly talking about the ways in which companies, through their everyday activities, contribute to wider social development, how they care for their environment, employees, vulnerable groups, etc. Simply, how and how much they have a positive impact on the sustainable development of their community. Through the activities of many experts, institutions and large companies, this concept has started to be recognized and inaugurated under the name "Corporate Social Responsibility", or shortly - CSR.

Social media as a useful tool, may help companies to share their information about CSR activities with millions of people. Thus, Social media plays very important role in how companies communicate and report CSR and act as good corporate citizens. Social media provide opportunities for companies to interact with their stakeholders and maintain authentic and permanent relations with them. Most importantly, social media is supporting companies in achieving a competitive advantage (Mangold \& Faulds, 2010). 
The concept of socially responsible business has become one of the key issues for leading companies globally. There is no big company in the world that strategically does not think about its social role, and almost no important institution that did not devote to the development and promotion of this topic. Many believe that this topic introduces change, reshape the world, and establishes standards for the assessment between good and big companies. William Clay Ford, Managing Board Chairman of the Ford Company, said in 2004: "There is a difference between a good company and a big company. A good company offers great products and services. The big company also offers great products and services, but it also tries to improve the world" (Kotler \& Li, 2007, 7).

The concept and practice of CSR relate to the overall range of its operations and to all the relationships that the company establishes. What a company produces, how it buys and sells, how it affects the environment, how it employs, trains and influences the development of its own people, how affects the social community and respects human and labor rights - all this determines the overall impact of the company on society. The positive and proactive functioning of the business sector in all these areas, above the level prescribed by the laws, has become an established practice in the developed world, primarily because it has been shown that everyone has the benefit of such a practice. On the global market, there are a huge number of companies that offer their goods and services, which leads to an increasingly intense competition in which only the best ones stand out. In order to achieve business excellence, it is not enough just to produce goods or offer a service of exceptional quality. That is why the leaders of multinational companies, which are often more powerful than some sovereign states, show an increasing interest in engaging and becoming equal partners in creating various sustainable state policies and practices, both at the micro and macro level of socioeconomic development.

Since the 1990s, the world has been confronted with the process of fragmentation of control mechanisms and the emergence of many new actors. Among these new actors, transnational corporations are those that have large, if not the biggest, importance and impact on all other actors. Many general tasks and duties were transferred from the government and non-governmental sector to the business sector, which resulted in an increase in the power and reputation of these activities in the social sphere. As the power grows, the responsibility of companies for society is also affected by their business activities. It has become necessary for companies not only to avoid harmful activities but also to take full responsibility for their own actions and become active in the overall advancement of society. That is why the CSR concept represents a fundamental and comprehensive change in the access to different sectors of society by all business participators: small, medium and large enterprises. Responsible business is one of the key solutions for achieving sustainable development, since it contributes to the harmonization of relations between the sphere of economy, as the main driver of development, and the interests of the society as a whole, which should not be ignored either. Sustainable development is a develop- 
ment idea that meets current needs, but considers the needs of future generations as well.

Today, most companies have included CSR as an integral part of their business model, i.e. as part of their business strategy and their competitive advantage. The Annual Report on CSR is published together with the annual financial statement. In order to have a positive impact on the community, culture, society and the environment in which they operate, companies must conduct their business, implementing the CSR principles (good employee treatment, environmental protection, transparency of governance, supporting philanthropy, strengthening human rights, respecting cultural differences, promotion of fair trade, etc.). Corporate philanthropy is one of the forms of corporate social responsibility and one of the ways in which a company can successfully and clearly demonstrate its values and beliefs to employees and partners, as well as clients and the public. Corporate philanthropy implies the support of companies to nonprofit organizations or cultural institutions, as well as institutions of social and health care, sports associations, etc. By providing support in money, products and services, the company, in fact, shows that it understands the needs of the wider community and the society in which it operates. Corporate philanthropy is also a business strategy that needs to be distinguished from sponsorship: while sponsorship represents a business relationship between a company and another entity, and it implies a service or action in exchange for money or some other resource, corporate philanthropy is a strategic response to community and society needs and means "giving", without expecting anything in return. Strategic approach to corporate philanthropy involves: identifying the goal of giving, the change that the company wants to make, the messages it wants to send, and identifying ways to give benefits that will make the funds invested efficiently and in the best possible way.

CSR for sustainable development is the priority on a board level (Kakabadse et al., 2009) of the responsible fashion retail business (Arrigo, 2013). In the last few years, the supply chain within the industry has become more demanding. This has a lot to do with the numerous scandals that bind to this industry. Famous companies such as Nike and H\&M are just examples of many companies that have suffered great losses, mainly because of how the production of these companies actually operates in terms of questionable working conditions. As a consequence, customers from all over the world began to demand from those companies to assume greater responsibility for their business and its impact on society. Consumers would like to see a more transparent supply chain, and they want to be sure that when they buy clothes, those clothes are produced from fair conditions (Svensson, 2009).

There is a strong business argument for the implementation of CSR in the supply chain of the fashion industry because it is an industry of high-profile. Poor CSR practices in subcontracting facilities may result in poor publicity, a boycott by consumers and a loss of brand value in the domestic market (Perry \& Towers, 2013). Sadly, a large number of em-ployees within this kind of companies, because of the 
fear of losing positions within the organization, are ready to accept the role of "blind executor" who approves of all the moves of the manager, even when they are aware that he/she makes mistakes (Baltezarevic, V. \& Baltezarevic, R., 2010).

\section{CORPORATE SOCIAL RESPONSIBILITY}

"The social responsibility of business encompasses the economic, legal, ethical and discretionary expectations that society has of organizations at a given point in time" (Kakabadse, A. \& Kakabadse, N., 2007, p. 15). CSR can be defined as "the view of the corporation and its role in society that assumes a responsibility among firms to pursue goals in addition to profit maximization and responsibility among a firm's stakeholders to hold the firm accountable for its actions" (Werther, et al., 2011, p. 5).

For Carroll $(1979,500)$ CSR is: "The social responsibility of business encompasses the economic, legal, ethical and philanthropic expectations that society has of organizations at a given point in time". When looking at the definition of CSR from country to country and even within countries themselves there are variations that may occur (Matten \& Moon, 2008). The World Business Council for Sustainable Development defines CSR as the commitment of business to contribute to sustainable economic development, working together with employees, society, and local communities to improve their quality of life (Holme \& Watts, 2000).

Windsor (2006) states that there are three main political and moral perspectives on CSR: the first one is called "ethical", second "economic"; and the third one, "corporate citizenship". CSR strategy impacts business by: "reducing costs and risk, maximizing profits and competitive advantage, increasing reputation and legitimacy and creating synergistic value" (Kurucz, et al., 2008, 86). "By building a business strategy to align economic, social and environmental performance to longterm business values, corporate social responsibility becomes part of the business and adds long-term value for both the company and the society" (Rochlin et al., 2005, p. 8).

Many researchers pointed out that the internal and external communication of corporate social responsibility efforts may result in the potential business benefits (Maignan et al. 1999). There are many differences between organizations, each of them with their own story about the achievements, company reputation, culture, people, products or services, but it is crucial for all of them to develop close relationships with their clients and coworkers. The organization should apply a quality communication to employees and to place the necessary information from anywhere at any time (Baltezarevic, V. et al., 2016). If there are communication barriers, the exchange of experience is made more difficult, the motivation of employees is discouraged, and there is dissatisfaction at work, which is exactly the opposite of the realization of joint activities of members and groups of organizations, in order to 
achieve high unity of employees and the feeling that they are inextricably linked with the organization (Baltezarevic, V. et al., 2010).

\section{THE PYRAMID OF CORPORATE SOCIAL RESPONSIBILITY}

One of the most frequently quoted concepts of socially responsible business is the concept of Carroll Archie, which he expressed through his famous pyramid of corporate social responsibility where he presented the social responsibility of the company as a pyramid. The pyramid bottom makes economic responsibility, followed by legal, ethical and philanthropic responsibility. Economic responsibility forms the basis of the pyramid because it is the basic goal of every enterprise, which is called the basic economic unit in the community. Carroll calls economic responsibility a basic one because all other types of responsibilities derive from it. Realizing the economic goal must be based on legal regulations, the business must be carried out in accordance with applicable laws, and this is another type of social responsibility - legal social responsibility. Ethical responsibility includes those activities and behaviors that are not prescribed by law and which are not sanctioned by the state as such, but which are expected from companies to recognize and respect certain ethical standards and values of a society. The fourth type of social responsibility at Carroll's pyramid is philanthropic responsibility. Under this type of social responsibility are activities that companies, as "good citizens", undertake, voluntarily, in order to improve the quality of life of community representatives, helping by providing the money and equipment to communities, education, culture, by enabling volunteer work of employees, etc. (Carroll, 1999).

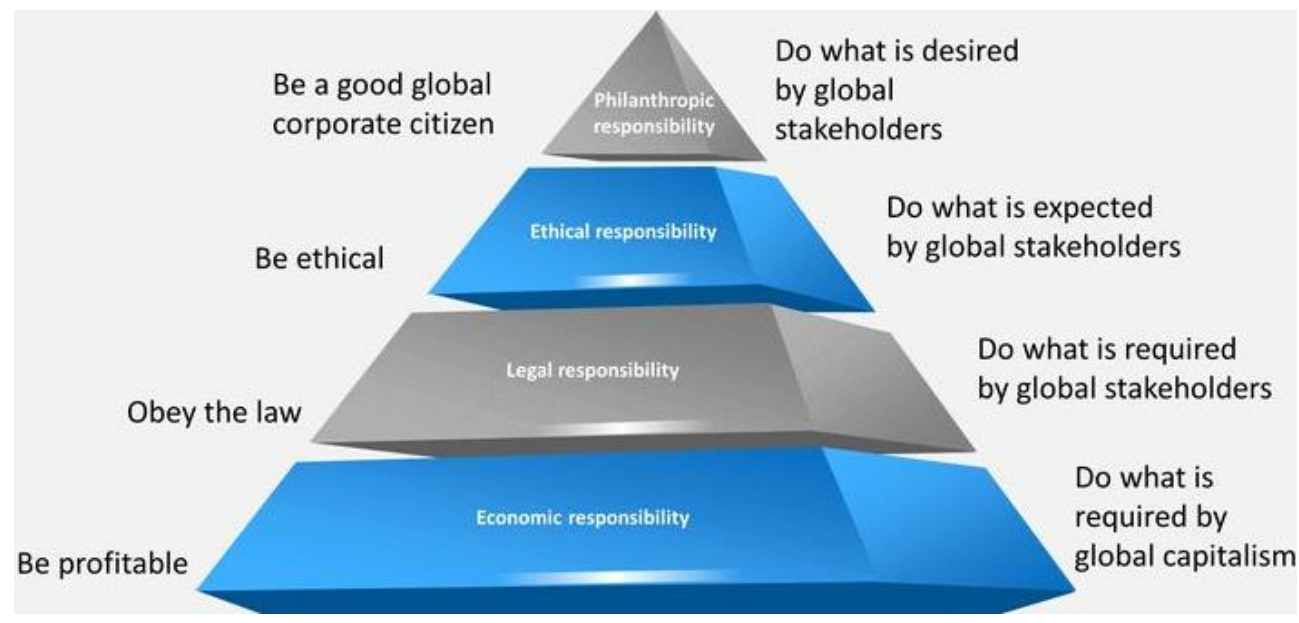

Figure 1. Carroll's pyramid of CSR

Source: Pharodix Foundation (2019) 
The pyramid of CSR is a tool suggesting what types of activities that are the basis for CSR and which ones that should be considered as more important (Szczanowicz \& Saniuk, 2016). It should be remembered that these layers have always existed in CSR, additionally philanthropic and ethical have been considered more important than before (Carroll, 1993).

\section{CORPORATE SOCIAL RESPONSIBILITY INSIDE THE FASHION INDUSTRY}

Many famous fashion brands are criticized in the media after committing controversial business practices. The child labor and generally very bad working conditions are still present in low-cost production countries. Many companies under public scrutiny started using CSR practices to reposition their corporate image (Sweeney \& Coughlan, 2008). More than 75 million people are working in the fashion industry; therefore, this industry is considered as one of the largest around the World (Stotz et. al., 2015). This industry, as one of the most important and dynamic sectors in the World Economy, generated more than 1.5 billion USD in 2008 (Jones et. al., 2012, p. 120).

However, the fashion industry has been accused of not taking enough responsibility for its actions towards sustainability issues (Claudio, 2007). This is a sensitive question because this industry relies on production in low-cost countries (De Brito et al., 2007) where, in many cases, safety and environmental regulations are questionable.

It is important for business sectors to formulate reliable strategies and to prevent the pollution of the environment they cause, the other issue, they need to solve is how they plan to utilize natural resources in the future (Chandler, 2017). This discussion is particularly important to the fashion industry, as they treated the natural resources as a "bottomless pit" (Tilley, 1999, 245), and production processes are mainly about "make and waste" (Ibid).

The fashion industry, as a broad industry, is divided into a slow and fast fashion which includes apparel, textiles, or clothing and footwear (Hines \& Bruce, 2007). Some authors concluded that slow fashion focuses on quality instead of the quantity (Jung \& Jin, 2016), while fast fashion focuses more on low price and massive production (Foroohar \& Stabe, 2005). The goods, associated with fast fashion retailers, are products that have a short life, particularly in the mass market. Therefore, lower labor and manufacturing costs mean lower costs overall (Joy et. al., 2012).

This industry, characterized by "dynamic consumer demand, shorter product life cycles and concentrated retail channels" (Locke, 2013, 126) is forcing the retailers to produce more, faster, better, and of course, cheaper (Locke, 2013). Usually, because of the tight delivery demands the fast fashion companies often use 
expedited shipping methods, i.e. by air (Joy et al., 2012), which significantly increase air pollution (Saicheua et al., 2012). Corporations often seem unaware of their contractors' problems until they see their name on media. Many companies, as a result of standard violations in their supplier's manufacturing facilities, are facing customer boycotts, and the negative adverse media publicity (Lawrence, 2002). Nowadays media audience can react against companies which do not take care of society only if the whole society engages in the media educating of the recipients of media messages (Baltezarevic, V. et al., 2014) because only the media literate audience can distinguish true company stories from those that have been prepared for advertising purposes.

Koszewska (2011) claims that it is the responsibility of the consumers to raise questions about the ethics of fast fashion and its meaning for our society. Consumers should guard and ensure the social conscience of the fashion industry. Finally, that may inspire numerous innovations in this industry.

Ndela (2015) proposes solutions for the development of the fashion company's CSR policy. He suggests an eco-packaging and an environmental-friendly production, in his opinion companies should get rid of unhealthy toxic materials, and to provide good salaries and safe working conditions for their employees.

However, CSR in fashion has been in practice for some time, and there are many positive examples in the fashion industry. Companies invest in sustainable production, develop animal welfare strategies or have special human rights directives. In the case of the Marks \& Spencer, a company that advertises itself as the most responsible supplier in the world, as CSR is treated as a company's main ideology (Grayson, 2011) as they pointed out that their goal is "to create a positive impact in society and improve peoples' lives wherever we touch them, in line with our company purpose by Making Every Moment Special" (Marks \& Spencer, 2019, p. 1).

It is important to mention some positive examples in the fashion industry that takes CSR seriously. Their strategies should inspire change and lead to better companies` practices. The brand Zara designed stores that are eco-friendly, where they use renewable energy for cooling and heating, furthermore, $90 \%$ of their packaging is made of paper, and the remaining $10 \%$ of the plastic they use is biodegradable. The hangers used in the stores are all recycled. The well-known company H\&M is delivering sustainable and affordable pieces to its customers. This company launched a collection made of recycled materials, where one-third of the cotton is completely organic.

Stella McCartney, considered as an ambassador of the green fashion movement, does not allow using animal-based products in her company. She is also a partner with a brand Adidas. They jointly produced the line which focuses on reusing the leftover fabrics and on minimizing the waste. Company Adidas is supporting and working with an organization Parley of the Oceans, together they are raising awareness about pollution of the oceans. As a symbol of their cooperation, company 
Adidas designed the first shoe made entirely from plastic waste founded in the ocean. The other example is the Lush cosmetics, very famous for bath and skincare products. All of their products are entirely vegetarian, and they also insist on using ecofriendly packaging (Thacher, 2019).

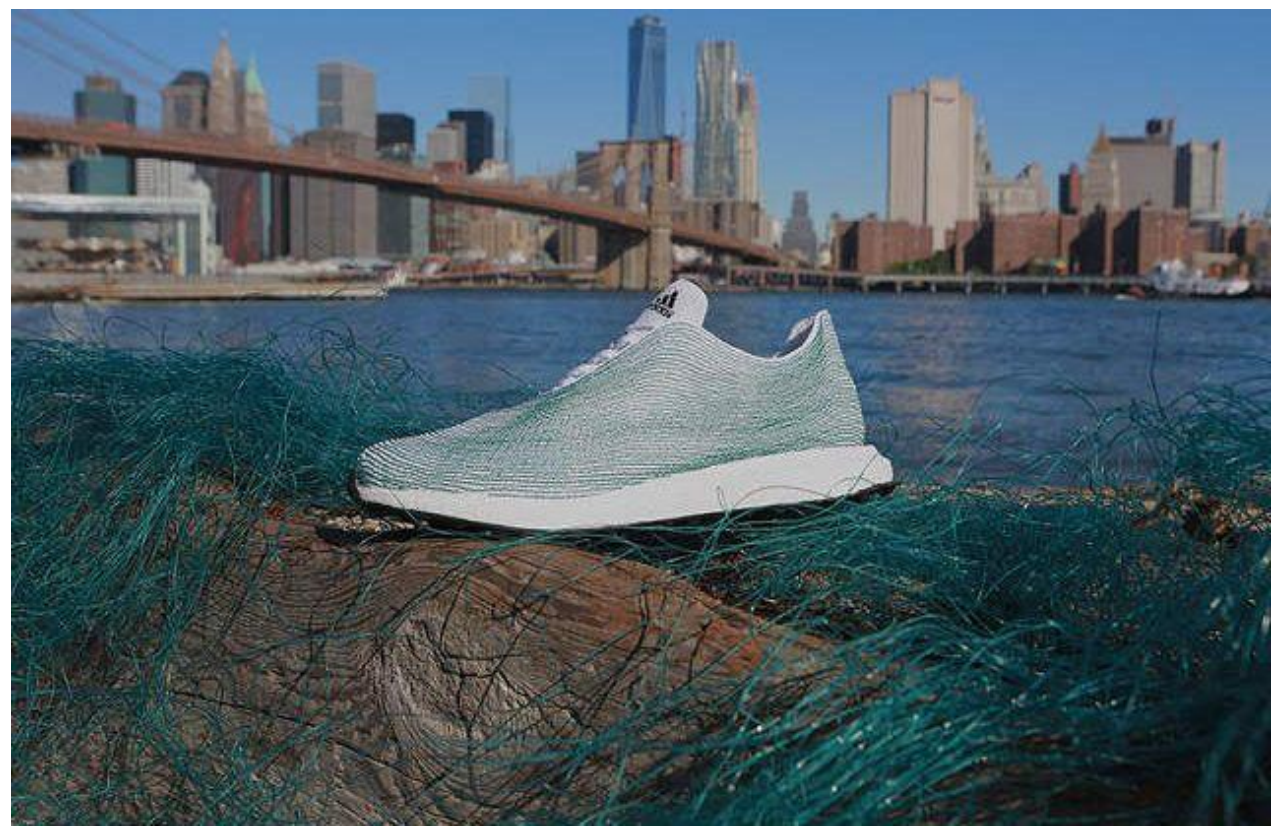

Picture 1. Adidas shoe made of Ocean Plastic

Source: Good News Network (2019)

\section{THE IMPORTANCE OF USING SOCIAL MEDIA FOR THE NEEDS OF THE CSR IN THE FASHION INDUSTRY}

Sweetser (2010), defined Social media as a series of online tools that encourage social participation and interaction. As Capriotti and Moreno (2007, p. 87) stated, "the Internet has become an essential space through which to diffuse information about corporate responsibility".

In modern environment, companies use online resources, such as social media channels corporate websites in order to communicate CSR to specific groups of stakeholders, instead of using traditional communication channels like TV, radio, newspapers, or bulletin board, for general stakeholders (Isenmann, 2006). "Social media is perceived by consumers as a more trustworthy source of information regarding products and services than corporate-sponsored communications transmitted via the traditional elements of the promotion mix" (Mangold \& Faulds, 2009, 360). Social 
media represent an excellent tool for engaging stakeholders and consumers in dialogues (Du, Bhattacharya, \& Sen, 2010).

According to Bilic (2010), sites at Social media are free, and has built-in interactivity. Bilic also added that, Social media altered how companies communicate with others and perform business. Strong Social media platform can empower and engage stakeholders to share their ideas and communicate with the company (Manchester, 2010), and represents a valuable resource for CSR communication and stakeholder involvement (Fieseler et al., 2010). Companies can be proactive at the moment of using Social media in order to engage stakeholders to be their advocates of CSR and spread CSR messages (Du et al., 2010).

According to Mangold and Faulds (2009, p. 358): "Social media have become a major factor in influencing various aspects of consumer behavior including awareness, information acquisition, opinions, attitudes, purchase behavior, and postpurchase communication and evaluation". These authors added that Social media have become the place for consumers to express and discuss their critical views of companies, since they consider Social media a more reliable source than the sources of traditional media (Mangold \& Faulds, 2009).

The development of Social media platforms has given consumers greater power than they have ever had before. Consumers now have taken over the power from public relations and marketing experts (Kietzmann et al., 2011). Therefore, Kietzmann et al. (2011, p. 250) noted: "customers no longer want to be talked at; instead, customers want firms to listen, appropriately engage, and respond". Capriotti (2011) stated, that the Social media will become more than the message of Corporate Social Responsibility, it will become the soul of CSR and, embedded as part of the brand and brand message. DiMauro (2011) added, that Social media in the fashion industry is enhancing the development of social fashion, where expertise are applied to support art.

\section{CONCLUSION}

Today companies are aware that they do not live alone on this planet and that they have to worry about society as a whole, not just to care about their own future. They know that doing business is not sustainable in the long run if it is focused exclusively on an achieving the profit and existence. By helping society, companies contribute to solving certain problems and improving the quality of life in the society in which they provide their services. On the other hand, when deciding to purchase some goods or services, customers are also interested in ethical issues related to the company's behavior towards the wider community. If individual companies use methods that are not ethical from a customer's point of view, they are willing to punish them by boycotting their products or services. Consequently, companies that 
think about their environment, about the needs of the local community in which they provide their services, are in strategic advantages over their competition.

Until twenty years ago, the philanthropic activity of a company that did not deal with and was not related to the economic goals of the company was dominant. It was supposed to do well and to leave an impression. There was no discussion about defining a business goal when granting help.

In today's modern society, where the need for environmental sustainability and social responsibility is given more attention, it is relatively easy for brands to damage its image by acting irresponsible. Since the disputable practices of unconscious companies caught the attention of the public, the main actors of the industry have started voluntarily publishing different types of reports (Turker \& Altuntas, 2014) in order to get their brand image back on track.

By applying this business strategy, companies from the fashion industry take a more favorable position on the market, increases market share, improves image, increases employee satisfaction, and develops a sense of community in society. The fashion industry, which generally does not have a positive global image, faces serious challenges to improve public opinion about its business. As mentioned in one of the examples in this paper, relating to Stella McCartney, companies need to start a change from themselves, and it is even recommended for managers to become the ambassadors of green fashion movement. But managers also have to take care of their team because without the participation of all team members they cannot reach the projected goals, as the attractiveness of the organization, or the attractiveness of belonging to a particular group, depends on the individual satisfaction of each member of the group with the work they perform (Baltezarević, V. \& Baltezarević, R., 2010).

However, a large number of positive examples from practice in this area are very encouraging. Awareness is changing and many companies in this industry begin to adapt their business, therefore they are not the only ones who benefit, but also the society in which they operate can feel the improvement. This can be achieved by taking care of the emissions of toxic gases from the factories, or by producing products by using only clean and natural materials, packing in biodegradable packaging and actively participating in the creation of environmental awareness, through the cooperation with various organizations in this field. By giving a personal example, companies may be considered as the leaders of positive change in this area.

Social media provide a new and more efficient way to communicate CSR efforts, since social media offer organizations the opportunity to directly interact with their consumers about these efforts and strategies in a way that other media cannot provide (Jahdi \& Acikdili, 2009). According to Mangold \& Faulds (2009), Social media presents higher levels of efficiency compared to traditional communication channels, by improving productivity and performance. Authors added, that social 
media plays a crucial role in how companies communicate and report CSR and behave as good and cooperative corporate citizens.

Companies by offering social media pages "can shape discussions in a manner that is consistent with the organization's mission and performance goals" (Mangold $\&$ Faulds, 2009, p. 361). Social media engage consumers much more than traditional media, and offers the opportunity for interaction, which can help organizations to get their customers engaged in their CSR efforts (Du et al., 2010).

\section{REFERENCES}

Arrigo, E. (2013), "Corporate responsibility management in fast fashion companies: the Gap Inc. case”, Journal of Fashion Marketing and Management, Vol. 17, No. 2, pp. 175-189.

Baltezarevic, V., Baltezarevic, R. (2010), “Corporate obedience”, Temida, Vol. 13, No. 3, pp. 83-96 (in Srbian).

Baltezarević, V., Baltezarević, R., Baltezarevic, B. (2016). "Intellectual property in the context of the contemporary society" International Review, No. 3-4, pp. 145150 .

Baltezarević, V., Paunkovic, J., Zikic, S., Baltezarevic, R. (2010), “The influence of communication on sustainable economic development", Proceedings the Conference on Strategic Management, University of Belgrade-Faculty in Bor, Belgrade, May 30-June 1, Kladovo, Serbia, pp. 106-107.

Baltezarevic, V., Baltezarevic, R., Milovanovic, S. (2014), "Between the lines and through the images", Informatoogia, Vol. 47, No. 1, pp. 29-35.

Bilic, I. (2010), „Development of Web Corporate Communications Function by Official Web Sites and Value Added Ranking: Case of Croatia“, The Business Review, Vol. 15, No. 1, pp. 151-158.

Capriotti, P., Moreno, A. (2007), „Corporate citizenship and public relations: The importance and interactivity of social responsibility issues on corporate websites“, Public Relations Review, Vol. 33, No. 1, pp. 84-91.

Capriotti, P. (2011), „Communicating corporate social responsibility through the internet and social media" in Ihlen, J.L. Barlett, and S. May (Eds.), The Handbook of Communication and Corporate Social Responsibility, pp. 358378, Wiley, New York, NY.

Carrol, A. (1999), "The Pyramid of Corporate Social Responsibility: Toward the Moral Menagement of Organizational Stakeholders", Business Horizons, July/ August, pp. 39-48.

Carroll A. (1993), Business and Society: Ethics and Stakeholder Management. College Division South-Western Publishing Co., Cincinnati.

Chandler, D. (2017), Strategic Corporate Social Responsibility-Sustainable Value Creation, 4th ed., SAGE, Thousand Oaks, CA, USA. 
Carroll, A.B. (1979), "A Three-Dimensional Conceptual Model of Corporate Performance", Academy of Management Review, Vol. 4, No. 4, pp. 497-505.

Claudio, L. (2007), "Waste couture: environmental impact of the clothing industry". Environmental Health Perspectives, Vol. 115, Noi. 9, pp. 448-454.

Good News Network (2019), Adidas test to sell shoes made of ocean plastic was so successful, they are going even further, https://www.goodnewsnetwork.org/ adidas-shoes-from-ocean-plastic-going-even-further/, Accessed 15.06.2019.

De Brito, M.P., Carbone, V., Blanquart, C.M. (2008), "Towards a sustainable fashion retail supply chain in Europe: Organisation and performance", International Journal of Production Economics, Vol. 114, No. 2, pp. 534-53.

Di Mauro, V. (2019), Fashion \& social media: Power to the people or the Publisher? Retrieved from https://www.business2community.com/fashion-beauty/fashionsocial-media-power-to-the-people-or-the-publisher-066459

Du, S., Bhattacharya, C., Sen, S. (2010), ,Maximizing Business Returns to Corporate Social Responsibility (CSR): The Role of CSR Communication", International Journal of Management Reviews, Vol. 12, No. 1, pp. 8-19.

Fieseler, C., Fleck, M., Meckel, M. (2010), „Corporate Social Responsibility in theblogosphere“, Journal of Business Ethics, Vol. 91, No. 4, pp. 599-614.

Foroohar, R., Stabe, M. (2005), "Fabulous fashion: low-cost companies like Zara and Topshopare emerging as defining and dominant players, not just followers". Newsweek International, $17^{\text {th }}$ October.

Grayson, D. (2011), "Embedding corporate responsibility and sustainability: Marks \& Spencer", Journal of Management Development, Vol. 30, No. 10, pp. 1017 1026.

Hines, T., Bruce, M. (2007), Fashion Marketing Contemporary Issues, 2nd ed., Elsevier Ltd., Oxford, UK.

Isenmann, R. (2006), „CSR Online: Internet Based Communication“ in J. Jonker, \& M. De White (Eds.), Management Models for Corporate Social Responsibility, pp. 247-263, Springer, Berlin.

Jahdi, K.S., Acikdilli, G. (2009), „Marketing Communications and Corporate Social Responsibility (CSR): Marriage of Convenience or Shotgun Wedding?", Journal of Business Ethics, Vol. 88, No. 1, pp 103-113.

Jones, P., Comfort, D. (2012), "Corporate Social Responsibility on the catwalk." Journal of Business and Retail Management, Vol. 7, No. 1, pp. 118-129.

Joy, A., Sherry, J. F., Venkatesh, A., Wang, J.,, Chan, R. (2012), "Fast Fashion, Sustainability, and the Ethical Appeal of Luxury Brands", The Journal of Dress, Body \& Culture, Vol. 16, No. 3, pp. 273-296.

Jung, S., Jin, B. (2016), "The approach, Sustainable Development of Slow Fashion Businesses: Customer Value. Sustainability, Vol. 8, No. 6, pp. 537-546.

Kakabadse, N.K., Kakabadse A.P. \& Davies, L.L (2009), "CSR leaders road-map". Corporate Governance, Vol. 9, No. 1, pp. 50-57.

Kakabadse, A., Kakabadse, N. (2007). CSR in Practice: Delving Deep, Palgrave Macmillan, New York. 
Kietzmann, H.J., Hermkens, K., McCarthy, I.P., Silvestre, B.S. (2011), „Social media? Get serious! Understanding the functional building blocks of social media“, Business Horizons, Vol. 54, No. 3, pp. 241-251.

Koszewska, M. (2011), "The role of consumers in the development of social responsibility in Poland, with particular emphasis on the textile and clothing market", Scientific Papers of the University of Economics in Wrocław, No. 220, pp. 327-334 (in Poland).

Kotler, F., Li, N. (2007), Corporate Social Responsibility, Cigoja, Belgrade (in Serbian).

Kurucz, E.C., Colbert, B.A., Wheeler, D. (2008), "The business case for corporate social responsibility", Chapter 4 in The Oxford Handbook on Corporate Social Responsibility, ed. A. Crane, A. McWilliams, D. Matten, J. Moon \& D. Seigel, pp. 83-112, Oxford University Press, Oxford.

Lawrence, F. (2002), "Sweatshop Campaigners Demand Gap Boycott", The Guardian, November 22, https://www.theguardian.com/uk/2002/nov/22/clothes. globalisation.

Locke, R.M. (2013), The Promise and Limits of Private Power, New York: Cambridge University Press, Cambridge.

Maignan, I., Ferrell, O.C., Hult, G.T.M. (1999). "Corporate citizenship: cultural antecedents and business benefits", Journal of the Academy of Marketing Science, Vol. 27, No. 4, pp. 455-469.

Manchester, A. (2007), How to use social media to engage employees: strategies to improve communication and collaboration, Melcrum Publishing, United Kingdom.

Mangold, G., Faulds, D. (2009), „Social media: the new hybrid element of the promotion mix“" Business Horizons, Vol. 52, No. 4, pp. 357- 365.

Marks, S. (2019), Community Engagement, https://corporate.marksandspencer.com/ sustainability/community-engagement, Accessed June 15, 2019.

Matten, D., Moon, J. (2008), "Implicit and Explicit CSR: A conceptual framework for a comparative understanding of corporate social responsibility", The Academy of Management Review, Vol. 33, No. 2, pp. 404-424.

Ndela, M.N. (2015) "Corporate Social Responsibility and Sustainable Living" in: Responsible Living: Concepts, Education and Future Perspectives, ed. V.W. Thoresen, D. Doyle, J. Klein \& R.J. Didham, pp. 83.96, Springer International Publishing, Switzerland.

Perry, P., Towers, N. (2013), "Conceptual framework development", International Journal of Physical Distribution \& Logistics Management, Vol. 43, No. 5/6, pp. 478-501.

Pharodix Foundation (2019), Carroll's CSR Pyramid and its applications to small and medium sized businesses, https://www.pharodix.com/carrolls-csr-pyramidand-its-applications-to-small-and-medium-sized-businesses, Accessed June 14, 2019. 
Holme, R., Watts, P. (2000), Corporate Social Responsibility: Making Good Business Sense, World Business Council for Sustainable Development, ConchesGeneva.

Rochlin, S., Witter, K., Monaghan, P., Murray, V. (2005), "Putting the corporate into corporate responsibility" in: Accountability forum: Corporate responsibility and core business, ed. P. Raymond, pp. 5-13, Greenleaf Publishing, London.

Saicheua, V., Knox, A., Cooper, T. (2012), "Sustainability in clothing supply chain - implications for marketing" in Proceeding of the 37th macro-marketing conference 13-16 June, pp. 284-307, Freie Universität, Berlin.

Stotz. L., Kane, G. (2015), Facts on Global Garment Industry, Clean Clothes Campaign, Amsterdam.

Svensson, G. (2009), "The transparency of SCM ethics: conceptual framework and empirical illustrations", Supply Chain Management: An International Journal, Vol. 14, No. 4, pp. 259-269.

Sweeney, L., Coughlan, J. (2008), "Do different industries report corporate social responsibility differently? An investigation through the lens of stakeholder theory", Journal of Marketing Communications, Vol. 14, No. 2, pp. 113-124.

Sweetser, K.D. (2010), „A Losing Strategy: The Impact of Nondisclosure in Social Media on Relationships“, Journal of Public Relations Research, Vol. 22, No. 3, pp. 288-312.

Szczanowicz, J., Saniuk, S. (2016), "Evaluation and reporting of CSR in SME sector". Management, Vol. 20, No. 1, pp. 96-99.

Thacker, H. (2019), "Seven Fashion Brands that takes SCR Seriously", CSR Journal, $18^{\text {th }}$ January. Accessed 14.07.2019, https://thecsrjournal.in/seven-fashionbrands- that-takes-csr-seriously/.

Tilley, F. (1999), "The gap between the environmental attitudes and the environmental behaviour of small firms", Business Strategy and the Environment, Vol. 8, No. 4, pp. 238-248.

Turker, D., Altuntas, C. (2014), "Sustainable supply chain management in the fast fashion industry: An analysis of corporate reports", European Management Journal, Vol. 32, No. 5, pp. 837-849.

Werther, W.B., Chandler, D. (2011), Strategic Corporate Social Responsibility, Stakeholders in a Global Environment, 2nd Edition, Sage Publications, London.

Windsor, D. (2006), "Corporate Social Responsibility: Three Key Approaches”. Journal of Management Studies, Vol. 43, pp. 93-114. 